\title{
Dekonstruksi patriarki khaled hosseini dalam novel a thousand splendid suns
}

\author{
Endang Suciati \\ Universitas Pesantren Tinggi Darul Ulum Jombang \\ endangsuciati@fbs.unipdu.ac.id
}

\begin{abstract}
The culture of patriarchy can be found in many quotations in A Thousand Splendid Suns novel. This kind of culture seems to dominate the woman. It can be seen that woman is considered weak. On the other hand, this novel also depicts the strength of woman that woman has braveness to fight againt and to control the man. Thus, the problem is about how this cultural of patriarchy is indeed deconstructed by this novel. This novel was analyzed using the concept of patriarchy by Kate Millet and deconstruction about hirarchy. The result shows that there is reversal of hirarchy between the man (Taliban leader, Rasheed, and Jalil) who are considered strong and powerfull and the women (Mariam, Laila, and Jalil's wives) who previously are considered subordinated. They are the women who are strong, have braveness to face the truth, responsibility, and have power to control the men. It shows that it is true that there is deconstruction about the culture of patriarchy which previously has been contructed by Khaleed Hossaeni in the novel.

Keywords: patriarchy, deconstruction, A Thousand Splendid Suns
\end{abstract}

\section{PENDAHULUAN}

Novel A Thousand Splendid Suns ditulis pada tahun 2007 namun cerita bekisar antara tahun 1954-2001. Novel ini banyak berbicara tentang kehidupan Afghanistan pada masa konflik baik karena perang dengan negara lain maupun dengan pemimpin dari negara sendiri. Novel ini ditulis oleh penulis Amerika yang berdarah asli Afghanistan. Ketika terjadi konflik di Afghanistan ia berhijrah ke Amerika bersama orang tuanya (ayahnya diplomat) yang mendapat suaka politik ke Amerika pada saat itu. Isu yang menonjol dalam novel ini adalah tentang kehidupan wanita yang mengalami penderitaan karena tekanan dari keluarga dan dari negara pada masa pergolakan dalam kepemimpinan Afghanistan. Sehingga tidak bisa dipungkiri lagi bahwa isu terhadap posisi wanita (karena berada dalam budaya patriarki) yang mengalami opresi baik di dalam dan di luar lingkungan domestik merupakan perbincangan hangat sepanjang sejarah masa suram Afghanistan.

Menurut Millet (2000: 25) masyarakat kita adalah masyarakat patriarki seperti halnya peradaban sejarah yang lain. Hal ini ditunjukkan dengan fakta bahwa ditangan laki- 
laki saja lah bidang-bidang seperti militer, industri, teknologi, ilmu pengetahuan bahkan penentu kebijakan berada. Melihat kenyataan ini, seakan patriarki adalah sebuah kewajaran meskipun ada pihak yang dikuasai dan yang menguasai yang merupakan esensi dari 'politik'. Di sinilah Millet mengaitkan patriarki denga politik dimana posisi-posisi penting di masyarakat dikuasai oleh laki-laki dan ketika posisi-posisi penting itu berjalan maka akan ada pihak yag dikuasai dan menguasai dan perempuan berada pada pihak yang dikuasai karena tidak berhak atas posisi-posisi tersebut.

Dalam sebuah artikel, Moghadam dalam Ghosh (2003) menyatakan bahwa isu hak perempuan di Afghanistan secara historis disebabkan salah satunya adalah karena sistem patriarkal yang sangat kuat terhadap gender dan relasi sosial pada masyarakat tradisional. Di sini terlihat jelas pula bahwa penyebab utama isu-isu terhadap perempuan muncul dan bahkan bisa dikatakan sepanjang sejarah (secara historis) dikarenakan kuatnya patrarki. Patriarki akan sangat berpengaruh terhadap gender dan relasi sosial (laki-laki dan perempuan) terutama pada masyarakat tradisional.

Demikian pula pernyataan haj-Yania (2005) tentang gender dalam tulisannya tentang masyarakat Palestina bahwa ketidaksetaraan gender memunculkan kekerasan yang dilakukan oleh laki-laki untuk mengontrol wanita dalam kehidupan keluarga dan bahkan dengan ini laki-laki akan mendapatkan keistimewaan dan pengakuan sebagai "laki-laki" di masyarakat yang patriarki. Pernyataan ini memperkuat betapa sistem patriarki -yang menguasai dan merugikan perempuan- justru menjadi kebanggan dan kewajaran (dengan adanya pengakuan) di masyarakat.

Dalam penelitian terdahulu, Wulandari (2012: 30) menunjukkan bahwa tokoh utama dalam novel tersebut (Mariam dan Laila) mengalami opresi dalam kehidupan mereka baik dari suami maupun dari negara dijelaskan pula upaya-upaya yang dilakukan untuk menghadapi opresi tersebut. Opresi yang dialami berupa tindakan penyiksaan bertubi-tubi oleh Rasheed (tokoh laki-laki yang dianggap sangat berkuasa) terhadap kedua istrinya (Mariam dan Laila) sekalipun mereka hanya melakukan kesalahan kecil misalnya tentang masakan yang disajikan.

Meskipun unsur patriarki sudah dikonstruksi sedemikian rupa dalam novel, ada unsur pembalikan yang dilakukan penulis. Kemudian hal ini akan dihubungkan dengan pengertian dekonstruksi yang disampaikan oleh Derrida bahwa dekonstruksi berhubungan erat dengan pembacaan yang cermat terhadap suatu teks. Pembacaan cermat tersebut misalnya sesudah mengintrogasi teksnya, menghancurkan pertahannannya dan 
menunjukkan bahwa seperangkat oposisi berpasangan ditemukan didalamnya. Oposisi itu tersusun atas hierarkis dengan menempatkan salah satu pasang sebagai yang istimewa. Kemudian, menunjukkan yang istimewa tersebut tergantung pada pengeksklusiannya atas yang lain dan menunjukkan bahwa keutamaan teks justru terletak pada yang disubordinatkan. (Sarup, dalam Faruk 2012: 217).

Dari hasil pembacaan terhadap novel A Thousand Solendid Suns, ada satu sisi dalam novel itu yang justru menunjukkan bahwa wanita adalah kuat, wanita mampu dan wanita bisa bersaing dengan laki-laki bahkan wanita bisa menundukkan laki-laki dalam kehidupan domestik. Hal inilah yang akan menjadi fokus pembahasan sehingga segala hal yang berkaitan dengan ketidakadilan gender karena budaya patriarkal akan ditentang sendiri oleh Khaleed dalam novelnya, sehingga patriarkal tersebut sebenarnya kabur meskipun secara kasat mata sistem patriarkal mendominasi cerita dalam novel ini.

Dengan berpijak pada konsep patriarki yang dikemukakan oleh Millet tentang kentalnya budaya patriarki dalam masyarakat yang tentunya menganggap perempuan sebagai pihak yang terdominasi serta konsep dekonstruksi Derrida yang berupaya menggoyahkan tatanan teks yang sudah dibangun, maka tulisan ini akan berusaha menyajikan oposisi biner yang terjadi karena budaya patriarki tersebut. Kemudian dilakukan pembalikan hirarki untuk menunjukkan bahwa yang dianggap subordinat sebenarnya adalah yang istimewa.

\section{METODE}

Metode yang digunakan dalam analisis ini adalah deskriptif kualitatif untuk menjelaskan data yang berupa kutipan dalam novel dan digunakan pula metode dekostruksi untuk mecari pembalikan hirarki yag telah dibangun oleh novel tu sendiri. Data yang dinalisis dalam bentuk kutipan baik berupa pernyataan penulis maupun ujaran dalam percakapan antar tokoh. Data tersebut dideskripsikan menurut konsep patriarki dengan dicari terlebih dahulu oposisi biner dan hirarki yang muncul. Selanjutnya deskripsi dilanjutkan dengan pencarian tentang pembalikan hirarki yang mematahkan konsep awal tentang patriarki yang telah membudaya dalam novel. 


\section{PEMBAHASAN}

Unsur patriarki yang ditunjukkan dalam novel A Thousand Splendid Suns sebagian besar terjadi dalam wilayah domestik atau kehidupan rumah tangga. Sang suami merasa dirinya bertanggung jawab terhadap istri mereka (jika istri lebih dari satu) misalnya dengan melarang mereka pergi sendiri, selalu memenuhi kebutuhan suami di rumah dan semenamena jika istri melakukan sedikit kesalahan. Dengan demikian terkesan bahwa laki-laki (suami) lebih berkuasa/lebih kuat sedangkan wanita (lebih lemah/tak berdaya). Inilah oposisi biner yang muncul dari budaya patriarki tersebut. Oposisi biner tersebut suatu ketika mengalami pembalikan hirarki dimana yang semula dianggap patriarki dengan berkuasa justru sang pengarang menunjukkan bahwa patriarki tersebut karena kekuasaan wanita di belakangnya. Berikut penjelasannya.

Unsur-unsur patriarkal yang dialami oleh tokoh sentral yaitu Laila dan Mariam bisa dilihat pula dalam, misalnya peraturan penguasa yang sudah diterapkan Rasheed dalam mengatur istri-istrinya, hal ini telah diterapkan pula oleh Taliban. Dalam hal ini Taliban (laki-laki/pemimpin yang memiliki power) yang benar-benar mengungkung kebebasan perempuan memegang otoritas penuh dalam masyarakat terkait aturan terhadap perempuan, seperti terlihat pada penyataan yang diumumkan oleh pihak Taliban yang berisi tentang: "Para perempuan harus berada dalam rumah. Mereka tidak diperbolehkan mondar-mandir atau keluyuran di jalan. Jika terpaksa mereka harus keluar rumah, harus ditemani oleh mahram atau saudara laki-laki. Jika tertangkap sendirian di jalanan, maka akan dipukul dan dipulangkan. Perempuan tidak diperbolehkan menampakkan wajah. Wajah mereka harus ditutup dengan burqa. Jika mereka tidak menutupnya maka mereka akan dihukum sangat pedih. Kosmetik dilarang. Perhiasan dilarang. Pakaian glamor dilarang. Tidak boleh bersuara. Tidak boleh berpandangan dengan laki-laki. Tidak boleh tertawa bebas di luar rumah. Tidak boleh mengecat kuku. Jika katahuan maka mereka akan kehilangan jarinya (Hosseini, 144).

Berdasarkan maksud dari kutipan di atas dapat dilihat bahwa perempuan menjadi perhatian utama dalam penegakan aturan dalam kehidupan masyarakat. Para perempuan tidak diperbolehkan keluar rumah -di jalanan- tanpa ada mahram. Jika melanggar maka mereka akan disakiti dan dipulangkan. Dalam hal berpakainpun demikian, mereka wajib menutup sekujur tubuhnya. Perempuan juga tidak boleh memakai kosmetik, perhiasan, pakaian gemerlap, dan berbicara lantang. Jika mereka melanggar akan ada hukuman 
baginya. Yang parah adalah mereka diancam dipotong jarinya jika diketahui menggunakan cat kuku.

Sebagai bagian dari masyarakat di sana, peraturan tersebut sangat memberatkan Laila dan Maryam karena mereka tidak bebas bergerak bahkan untuk tertawa dan bersuara saja di larang. Hal ini seolah membuktikan bahwa laki-laki -yang diwakili pihak taliban- begitu menekan pihak perempuan dan perempuan terkesan tidak berdaya, bagaimanapun mereka harus melakukannya.

Dalam urusan domestik yang menjadi isu sangat hangat di Afghanistan tersebut telah dialami Maryam dan Laila. Ketika mereka menjadi istri Rasheed, mereka tidak boleh beraktifitas di luar rumah. Selain itu, jika keluar rumah suami mereka mengharuskan memakai Burqo - pakaian yang menutup sekujur tubuhnya termasuk wajah, seperti paksaaan halus pertama Rasheed kepada Maryam You'll get used to it," Rasheed said. "With time, I bet you'll even like it (Hosseini, 42). Proteksi yang berlebihan yang ditunjukkan oleh Rasheed ini jelas menunjukkan bahwa perempuan dianggap lemah, tidak mampu menjaga diri sendiri. Pakaian itu harus digunakan, harus dipaksa digunakan untuk menumbuhkan kebiasaan -kebiasaan yang menekan bagi perempuan.

Unsur patriarki ini juga dapat dilihat ketika proses mereka menikah, hal ini ditunjukan oleh ayah Mariam, Jalil, yang dengan semena-mena bersama tiga istrinya menjodohkan Mariam dengan laki-laki yang lebih tua (Rasheed) tanpa persetujuan Mariam, seperti ungkapan salah satu istri Jalil Actually, your father has already given Rasheed his answer (Hosseini, 30). Jawaban yang dimaksud adalah Mariam telah setuju untuk menikah, padahal ia baru sehari berada di rumah ayahnya setelah ibunya meninggal. Mariam dalam hal ini tidak bisa berkata-kata lagi, apalagi mempertahankan diri. Ayah Mariam telah menentukan dan memutuskan laki-laki unuk menjadi suaminnya tanpa meminta persetujuannya terlebih dahulu. Di sini suara hati perempuan tidak didengarkan. Ayah adalah sosok patriarki terhadap anak perempuannya, dalam kasus ini tentang perjodohan.

Demikian pula dengan Laila, dia sangat terpaksa mau menikah dengan Rasheed karena hanya rumah Rasheed lah tempat berlindung dalam kondisi konflik setelah orangtuanya meninggal. Seperti yang diungkapkan Rasheed ketika ingin menikahi Laila, What of it? What? She's too young, you think? She's fourteen. Hardly a child. You were fifteen, remember? My mother was fourteen when she had me. Thirteen when she married (Hosseini, 114). Rasheed yang sudah tua akan menikahi Laila yang masih berumur 14 tahun. Ketika berbicara dengan Mariam, istrinya, Rasheed mengungkapkan keyakinannya bahwa 
Laila telah berumur cukup untuk menikah. Rasheed menentang pernyataan istrinya jika usia laila terlalu muda. Rasheed membandingkan dengan istrinya sendiri pada saat menikah dengannya telah berusia 15 tahun. Iapun menegaskan kembali bahwa ibbunya melahirkan dia ketika berusia 13 tahun. Hal ini dia katakan untuk memberi kebenaran bahwa sudah layak jika ia menikahi Laila yang berumur 14 tahun walaupun zaman ibu Rasheed dengan zaman Laila saat itu bisa saja berbeda. Namun tetap laki-laki berhak memaksa perempuan dalam kondisi ini. Maka patriarki terlihat sangat gamblang.

Beberapa contoh kutipan di atas membuktikan bahwa dua tokoh perempuan, Mariam dan Laila, berada pada posisi tersubordinasi, mereka dianggap lemah, tunduk pada laki-laki baik laki-laki tersebut penguasa dalam masyarakat, ayah, calon suami, dan suami mereka sendiri.

Di sisi lain, Khaleed Hosseini sebenarnya menolak unsur patriarki tersebut, hal ini dapat dilihat ketika wanita justru yang mengontrol laki-laki, laki-laki berada di bawah kuasa wanita. Contoh yang jelas dialami oleh ayah Mariam, Jalil, ia memaksa Mariam menikah dengan Rasheed karena dorongan dari istri-istri mereka, ia tidak ingin dipermalukan di depan istri-istrinya As Jali's wives began a new-and more sprightly-round of reassuring, Mariam looked down at the table. (Hosseini, 30). Kalimat bujukan tersebut agar Mariam mau menikah dengan Rasheed, sementara Jalil hanya diam. Di sini terlihat jelas bahwa sosok Jalil yang seakan memaksa ternya ada istri-istri nya yang menjadikan dia tidak bisa berkata apaapa. Paksaan itu sampai mengakibatkan Mariam memohon pembelaan dari Jalil, namun Mariam tidak kunjung dibela, karena jalil tidak mampu melawan kehendak istri-istrinya. Mariam terus meminta Jalil membantu mengatakan pada istriistrinya: Tell them. Tell them you won't let them do this. (Hosseini, 30). Ini merupakan bukti bahwa laki-laki sebenarnya bukan yang kuat tetapi lemah adalah ketika Jalil tidak mampu membela Mariam di hadapan istri-istrinya. Jalil dalam hal ini berada pada posisi yang tersubordinasi, justru perempuan yang mendominasi.

Persetujuan Laila ketika menikah dengan Rasheed sebenarnya bukan hanya karena butuh perlindungan saja namun ada ide licik Laila yang disembunyikan dari Rasheed, sampai Rasheedpun terperdaya. Ia mau menikah karena sudah mengandung anak Tariq, pacarnya, yang berpisah karena kondisi konflik. Seperti yang disampaikan oleh penulis:

She knew that what she was doing was dishonorable. Dishonorable, disingenuous, and shameful. And spectacularly unfair to Mariam. (Hosseini, 117). 
Dia sadar jika perbuatannya dahulu dengan Tariq sangat memalukan, namun ia ingin bersandar dengan menjadi istri Rasheed dengan demikian seolah-olah bayi yang dikandung adalah anak Rasheed, dan Rasheed percaya jika bayi itu adalah anaknya. Lagi-lagi kutipan ini membuktikan bahwa perempuan -Laila- lebih cerdik dan dapat mengelabuhi laki-laki. Laki-laki seolah tampak memaksa, menikahi perempuan belasan tahun, dibalik semua itu, perempuan justru menguasai pikiran laki-laki dengan cara mengelabuhinya meski yang tampak dari luar perempuan seolah yang kalah.

Contoh berikutnya tentang dobrakan terhadap patriarki ini adalah dalam keluarga Laila semasa kecil sebelum dia menikah. Ayah Laila adalah orang terpelajar, seorang guru, namun di dalam rumah, istrinyalah pengendali segala keputusan, istrinya tidak mau diatur oleh suaminya, dan sang suamipun menurut saja bahkan ketika situasi konflik semakin parah, untuk segera pindah, ayah Laila masih menunggu keputusan istrinya, Mammy. Seperti yang ayah Laila katakan, She's agreed!" he said, his voice tremulous with suppressed excitement- "We're leaving, Laila. All three of us. We're leaving Kabul" (Hosseini, 104). Ini membuktikan bahwa laki-laki di dalam keluarga tersebut bukan penentu keputusan, tidak memiliki kuasa. Kutipan tersebut juga menegaskan bahwa ayah Laila tampak tidak yakin dengan keputusannya -hanya untuk meninggalkan Kabul saja- ia masih menunggu keputusan dari istrinya. Di sini, ditunjukkan lagi bahwa patriarki tidak lagi berlaku.

Pertengkaran ayah dan ibu Laila seringkali terjadi, sampai-sampai dinyatakan bahwa, Downstairs, her parents were fighting. Again. Laila knew the routine: Mammy, ferocious, indomitable, pacing and ranting; Babi, sitting, looking sheepish and dazed, nodding obediently, waiting for the storm to pass (Hosseini, 60). Dalam pertengkaran tersebut, ibu Laila, Mamy, yang dominan, garang dan mengomel, sementara ayahnya, Babi, hanya duduk diam tanpa melawan menunggu ibunya berhenti. Ini merupakan salah satu bukti pula bahwa laki-laki yang digambarkan dalam keluarga tersebut tunduk terhadap istrinya. Laki-laki tidak berani membantah ketika terjadi konflik dengan istrinya, ia membiarkan istrinya menyerang kemudian dengan pasrah, tunduk, dan menggangguk, lakilaki didominasi oleh perempuan -istri.

Tidak hanya itu, kembali ketika Mariam dan Laila telah menjadi istri Rasheed dan mereka mengalami berbagai tindakan kekerasan dalam rumah tangga. Mereka selalu melakukan perlawanan meskipun sering kalah. Namun pada suatu ketika Khaleed Hosseini benar-benar menunjukkan bahwa wanita pun kuat, wanita tidak selamanya dikuasai oleh laki-laki. Buktinya yaitu Mariam berhasil membunuh Rasheed ketika mereka bertiga 
berkelahi dan Rasheed akan membunuh Laila. Mariam saw that she was no longer struggling. He's going to kill her, she thought. He really means to. And Mariam could not, would not, allow that to happen. (Hosseini, 182). Dalam kutipan di atas Mariam menyaksikan bahwa Laila tidak kuasa lagi untung menyerang Raheed dalam perkelahian mereka she was no longer struggling, Mariam juga yakin bahwa Rasheed akan membunuh Laila. Dalam situasi tersebut, Mariam tidak akan membiarkan Laila mati ditangan Rasheed, maka ia yang akan lebih dahulu membunuh Rasheed. Mariam dalam kutipan ini sempat menyaksikan kekejaman Rasheed terhadap Laila dan Mariam tidak tinggal diam, iapun turun tangan berupaya melawan dan membunuh Rasheed.

Setelah berhasil membunuh Rasheed, Mariam tidak sembunyi atau melarikan diri, namun ia mempertanggung jawabkan apa yang telah ia perbuat, siapapun yang salah, siapapun atau apapun yang menyebebkan ia membunuh bukan alasan membela diri. Mariam, tokoh perempua, menunjukkan sikap bertanggung jawabnya dengan sangat berani.

Di dalam penjara ketika Mariam bertanggung jawab atas pembunuhan yang dilakukan (ini juga suatu bukti bahwa wanita lebih bertanggung jawab dari pada laki-laki) dikatakan bahwa dialah satu-satunya wanita yang dipenjara karena kasus pembunuhan karena semua tahanan wanita adalah karena kasus keluar rumah sendirian, melanggar batas. Seperti terdapat dalam kutipan, None of the women in Mariam's cell were serving time for violent crime-they were all there for the common offense of "running away from home." (Hosseini, 190). Di situ dijelaskan bahwa tidak ada tahanan wanita yang dipenjara karena kasus kriminal (pembunuhan) seperti Mariam, rata-rata yang dipenjara di sana karena kasus kabur dari rumah. Hal ini juga menunjukkan bahwa wanita mampu dan berani serta bertanggung jawab atas perbuatan yang dilakukan. Sosok Mariam yang dari awal dianggap tersubordinasi oleh laki-laki ternyata justru malah pemberani dan memiliki tanggung jawab.

Selain itu, ayah Nana dan Jalil, termasuk figur lemah yang tidak memiliki kemampuan membela kebenaran bahkan tidak memiliki tanggung jawab atas perbuatan yang telah dilakukan. Seperti yang diungkapkan Nana untuk ayahnya, I wish my father had had the stomach to sharpen one of his knives and do the honorable thing. It might have been better for me (Hosseini, 6). Kutipan ini menunjukkan bahwa sosok ayah tidak mampu melakukan sesuatu untuk kebaikan anaknya, tidak berani menghadapi kebenaran. Laki-laki -ayah Nana di atas- tidak berani melawan dengan senjata yang dimiliki untuk memperjuangkan anak kandungnya, ia malah menutupinya. Sementara sosok Jalil seperti yang diungkapkan Nana pula bahwa Jalil didn't have the 'dil' either, Nana said, to do the 
honorable thing. To stand up to his family, to his wives and inlaws, and accept responsibility for what he had done (Hosseini, 6). Jalil lebih takut kepada istrinya karena telah berbuat salah pada Nana, dia tidak memiliki keberanian membela Nana bahwa dia tidak bersalah. Tampak sekali kutipan ini bahwa Jalil -sosok patriarki- justru malah tidak memiliki keberanian membela anaknya, menghadai kebenaran, dan menerima tanggung jawabnya.

Di akhir cerita, ketika Taliban yang menduduki Afghanistan telah mundur, salah satu tokoh sentral Laila menikmati kehidupan bersama suaminya, Tariq, merasakan kebebasan yang telah diidamkan oleh ayahnya, sebenarnya Ayah Laila pun merasakan bahwa ia tidak menyutujui ketidaksetaraan tersebut, dengan kata lain ia menentang patriarki. Seperti ingatan laila akan ucapan ayahnya, Of late, she has started hearing Babi's voice in her head. Dia ingat bahwa ayahnya mengatakan jika suatu saat annti Laila bisa menjadi apa saja yang dia inginkan, jika perang Afghanistan telah usai maka ayahnya yakin bahwa Afghanistan membutuhkan dirinya. Ucapan tersebut juga disetujui oleh ibu Laila. Ingatan Laila akan ucapan ayahnya ini membuktikan bahwa ayahnya di masa lalu sudah memiliki pemikiran bahwa ayahnya menghendaki perempuan untuk "merdeka" bisa menjadi apa yang diinginkannya, bebas, tidak ditekan oleh penguasa dan aturan-aturan yang dibuat oleh penguasa -laki-laki.

Dari berbagai kutipan tersebut dapat ditarik benang merah bahwa meskipun seolaholah patriarki telah mendarah daging, mengurat nadi dalam kehidupan masyarakat Afghanistan, Khaleed menyampaikan pesan tersembunyinya bahwa patriarki dalam novel tersebut sebenarnya tidak ada, yang ada adalah tindakan yang dilakukan karena wanita, ingin terhormat dihadapan masyarakat juga karena wanita dalam kehidupan rumah tangganya. Hal ini dapat dilihat bahwa ada pembalikan hirarki dari oposisi biner yang dibangun dalam budaya patriarki. Laki-laki yang dianggap berkuasa dan kuat dalam novel justru ditampilkan wanita yang lebih memiliki kekuatan dan keberanian.

\section{KESIMPULAN}

Berdasarkan uraian di atas dapat diambil kesimpulan bahwa, novel Khaled Hossini secara kasat mata memotret sisi kelam kehidupan wanita pada masa konflik berkepanjangan di Afghanistan. Dengan penggambaran tokoh utama Mariam dan Laila yang selalu mengalami opresi karena budaya patriarki, seakan-akan mereka berada di bawah kuasa lakilaki. Patriarki yang telah tumbuh sepanjang sejarah seolah-olah terjadi dengan wajar. Di satu 
sisi, novel in juga menampilkan sisi-sisi kekuatan wanita yang pada akhirnya memunculkan bahwa laki-laki yang semula dianggap berkuasa dan kuat justru malah lemah. Sehingga di sini terjadi pembalikan hirarki bahwa sebenarnya budaya patriarki tersebut tidak ada. Pada dasarnya laki-laki dan wanita pun memiliki kekuatan yang sama ketika mereka tidak di doktrin dengan aturan negara yang mengungkung dan perlakuan laki-laki yang menganggap diri mereka lemah.

\section{DAFTAR PUSTAKA}

Ahmed-Ghosh, Huma. 2003. <A History of Women in Afghanistan: Lessons Learnt for the Future or Yesterdays and Tomorrow: Women in Afghanistan> Journal of International Womenís Studies, Vol 4.

Faruk. 2012. Metode Penelitian Sastra. Yogyakarta: Pustaka Pelajar

Haj-Yahia, Muhammad M. 2005. < On the Characteristics of Patriarchal Societies, Gender Inequality, and Wife Abuse: The Case of Palestinian Society> Adalah's Newsletter, Vol. 20. Diakses dari http://adalah.org/newsletter/eng/nov05/fet.pdf pada 6 Juni 2013.

Hosseini, Khaled. 2007. A Thousand Splendid Suns. New York: Riverhead Books.

Millet, kate. 2000. Sexual Politics. Chicago: University of IllinoisPress.

Wulandari, Sri. 2012. The Oppression against Women in Afghanistan Portrayed in Khaled Hosseini's A Thousand Splendid Suns. Jombang: Fakultas Bahasa dan Satra Universitas Pesantren Tinggi Darul Ulum. Skripsi tidak diterbitkan.

http://www.khaledhosseini.com/hosseini-bio.html 